\title{
Phonics Reading Strategy: An Alternative Strategy to Improve EYL Students' Reading Skill
}

\author{
Fitri Arniati ${ }^{1}$, Sri Ningsih ${ }^{2}$, Devianti Devianti ${ }^{3}$, \& Arma Amir Hamzah ${ }^{4}$ \\ $1,3,4$, STKIP YPUP Makassar. Indonesia \\ ${ }^{2}$ Akademi Kebidanan Tahirah Al Baeti Bulukumba. Indonesia \\ fitriarniati168@gmail.com
}

\begin{abstract}
ARTICLE HISTORY
$\begin{array}{ll}\text { Received } & : 2019-03-18 \\ \text { Revised } & : 2019-03-21 \\ \text { Accepted } & : 2019-06-28\end{array}$
\end{abstract}

\section{KEYWORDS}

Pre-experimental Method Phonics Strategy Reading Skill

EYL

\begin{abstract}
The introduction of English to young learners has been implemented for a long time with various strategies and approaches. However, not all of strategies the teacher used were successful in being applied in the classroom. Based on preobservation, the students' reading interest has difficulty understanding the text. They have difficulty understanding sentences, and students can only find the meaning of the sentence or only understand the text content's outline. The present study aims to determine whether reading phonics strategy can improve students reading skill in second-grade of SMP Negeri 2 Sumarorong. The study used a pre-experimental method in one class given a pre-test and a final test. The population is the second-grade students and used a total sampling technique. The result of the data shows that the mean value in the final test is greater than the mean value of the initial test $(79.52>60.800)$, and the t-test value is greater than the t-table value $(12.046>2.046)$ at the level of increase of 0.05 , with degrees of freedom (df) 24 . This increase can also be seen from the post-test result, which is greater than the pre-test score. This evidence highlighted phonics reading strategy can improve students reading skill.
\end{abstract}

\section{Introduction}

Reading is considered a decoding skill, that is, inter printing code into ideas. People consider reading is an important activity, so people usually say that reading is a window to the world. Somadayo (2011, p.4) defines that reading is an interactive activity to pick and understand the meaning contained in written material Developed societies will always make reading activities a necessity of life that must be fulfilled. Therefore it is important for us to cultivate the habit of reading from childhood. Suganda (2015) states the reading and writing skills allow students to communicate more effectively, which is the primary goal of language learning. Cultivating reading habits and reading interest in children certainly require a big role from parents, especially teachers.

The English language has an alphabetic writing system that represent both phonemes and morphemes (Robertson and Deacon, 2019). The introduction of English to young learners has been implemented for a long time with various strategies and approaches. Zein (2017) says any language teaching strategy must be deeply rooted in the essence of second language learning. However, not all of the methods that the teacher used were successful in being applied in the classroom. Gray and Climie (2016) add that the reading process is often affected by the reader's language comprehension, expressive language skills, and overall metalinguistic ability (i.e., the ability to conceptualize language as an object of thought). From the teacher's point of view, the teacher's way affects reading text students' improvement. Unclear explanations, talking too fast, and teachers use monotonous techniques. It comes from the class material and atmosphere. The material used is less attractive, such as text containing foreign words, it makes students feel overwhelmed and challenging to learn.

The researcher conducted the pre-observation by interviewing the English teachers at SMP Negeri 2 Sumarorong. It was found that the majority of the grade 2 students had difficulty in reading English text. From the results of the pre-observations and interviews, several facts indicate this problem. First, students' reading comprehension is still low and having difficulty understanding the text. They have difficulty understanding sentences, and can only find the meaning of the sentence or only understand the text content's outline. Students need much time to understand the text, and they also do not take the opportunity to read English texts or in English lessons at home. Therefore, students have difficulty their exercises. It all makes their achievement low and causes failure in the teaching and learning process. 
The problems that often arise could be come from teachers, students and outside teachers. In addition, the classroom environment factor is also a determinant to encourage children's motivation to learn. Such problems have become commonplace in the world of education and deserve attention. Hence, teachers must innovate in determining appropriate strategies and approaches, which can increase children's interest and habits in reading. one way that can be tried is a phonics reading strategy. Phonics reading strategy is a way of teaching multisensory reading and writing of letters, then uses the sound synthesis method to read words (Retnomurti, Hendrawaty and Nurhayati, 2019). In the phonics check, the child is assessed independently by their teacher and asked to read aloud 20 words and 20 pseudowords (Double et al., 2019; Paris, 2019).

Some previous study are related to this research about phonics reading strategy. Firstly, Amadi and Offorma (2019), in their research entitled "Original Papers of Effects of Two Phonics Instructional Modes on English as Second Language Learners' Achievement in Reading," phonics is one of the contents of the curriculum that describes the relationship between letters and the sound of a language. It is used to convert written symbols into speech sounds. In other words, phonics establishes the relationship that exists between written and spoken language.

De Freitas, Da Mota and Deacon (2018), in her research entitled "Morphological Awareness, word Reading, and reading comprehension in Portuguese" investigates the unique effects of phonological awareness on several aspects of reading. The results showed that morphological awareness was a significant predictor of word reading accuracy. Morphological awareness also explains the unique differences in the understanding of the reading words as a control. Further, Menin-Sicard and Sicard (2017), in their researcher entitled "Phono-articulatory disorders and intelligence: the role of lingual and palatal reading," Demonstrating the relationship between disability and methodical and specific articulation disorders can improve not only speech intelligibility but also phonological awareness, which is known to be necessary for reading access.

It is the reason beyond the researcher researching SMP Negeri 2 Sumarorong using "Reading Phonic strategy." Applying reading phonic students can improve the ability to read the text correctly in the teaching and learning process by highlighting an essential question in the research "Does Phonics Reading improve second-grade students' reading ability at SMP Negeri 2 Sumarorong? To determine whether Phonics Reading could improve the reading ability of second-grade students. It was expected to be useful for English teachers to improve students' achievement, especially in reading. It is hoped that it can also be a valuable contribution for future researchers who wish to research similar research.

\section{Method}

This research used the pre-experimental method with one group pre-test, treatment, and post-test.

The statistic representation of the design as follows :

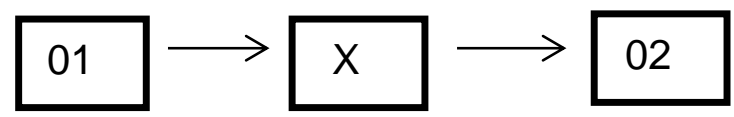

Where :

$01=$ Pre-test

$\mathrm{X}=$ Treatment

02 Post-test

\subsection{Variable of the Research}

This research consists of two variables:

1) Dependent Variable

The dependent variable of the research is the students reading ability.

2) Independent Variable

The independent variable of the research used phonics reading of learning.

\subsection{Population and Sample}

This research population was the second-grade students of SMP Negeri 2 Sumarorong academic in the year 2020/2021. The total number of students was 25 students due to there was only one class of second grade of SMP Negeri 2 Sumarorong. The researcher used the total sampling technique in taking the sample. The researcher took this class because they are still low in English, especially about reading.

\subsection{Instrument of the Research}

The research instrument was multiple choices of pre-test and post-test in phonics reading. The researcher gave 25 questions to the students. The pretest was used to measure the students' reading ability before presenting Phonics Reading Strategy. Furthermore, the post-test is used to determine whether there is an increase in students' reading ability through phonics reading after given the treatment.

\subsection{Technique of Data Analysis}

The data obtained from the test were analyzed using the following procedure:

1) Scoring the result of pre-test and post-test of the students' answer :

$$
\begin{aligned}
& \text { The student's correct answer }=4 \\
& \text { The student's wrong answer }=0 \\
& \text { Score }=\frac{\text { Total Correct Answer }}{\text { Number of Items }} \text { X } 100
\end{aligned}
$$


2) They are classifying the score of the students.
a) Score 91 - 100 classified as very good
b) Score 81-92 classified as good
c) Score $73-80$ classified as fairy good
d) Score $65-72$ classified as fair
e) Score 53-64 classified as poor
f) Score $0-52$ classified as very poor

3) Computing the frequency of the rate percentage of the students' score :

$$
\mathrm{P}=\frac{F}{N} \times 100 \%
$$

Where :

$$
\begin{array}{ll}
\mathrm{P} & : \text { Percentage } \\
\mathrm{F} & : \text { Frequency } \\
\mathrm{N} & \text { : Total number of students }
\end{array}
$$

4) Calculating the mean score of the students by using the following formula:

$$
\mathrm{X}=\frac{\sum \mathrm{x}}{N}
$$

Where :

$$
\begin{aligned}
& \mathrm{X}: \text { Mean Score } \\
& \sum \mathrm{X} \text { : The sum of all score } \\
& \mathrm{N}: \text { The total number of subject }
\end{aligned}
$$

\section{5) Calculating the result of the test}

To assess the varying significance between the pretest score and the post-test researcher, the test value was determined using the following formula:

$$
\mathrm{t}=\frac{D}{\sqrt{\Sigma D 2-\frac{(\Sigma D)^{2}}{N(N-1)}}}
$$

Where:

$$
\begin{aligned}
& \mathrm{t}: \text { test of significance } \\
& \mathrm{D} \quad \text { : score change } \\
& \sum \mathrm{D}: \text { the man of different score } \\
& \mathrm{N}: \text { total number of sample }
\end{aligned}
$$

\section{Findings}

The research findings related to statistical analysis results, namely the students' scores on the pre-test and post-test, the classification and percentage of students scores, the mean score, the t-test, and hypothesis testing. It has been explained in the previous chapter that the purpose of this study was to find out whether Phonics Reading could improve the reading ability of grade 2 students at SMP Negeri 2 Sumarorong. It was also stated that the data was collected through multiplechoice tests. Multiple-choice tests were presented twice, namely pre-test and post-test, which aimed to determine whether there was a significant increase in reading comprehension after providing treatment using Phonic Reading or not. The pre-test is given to students before giving the treatment which aims to determine the students' initial knowledge of reading skills and the post-test is given afterwards, which aims to determine the student's achievement in reading ability. The pretest and post-test were compared to investigate if there was a significant improvement in student's reading ability in both tests.

This study's findings relate to the description of students' pre-test and pre-test scores, treatment descriptions, post-test descriptions, and students' scores on post-test and research classification. The post-test frequency and percentage of students scores, mean and total scores, comparison between pre-test and post-test, t-test scores, and presentation of hypotheses. These findings are clarified as follows: students score on the pre-test (X1) and post-test (X2), the gain or difference with the matched pair (D1), and the profit squared (D2). Table 1 shows the pre-test and post-test scores in improving reading ability by phonic reading. The total pre-test score is 1.520 , and the total post-test is 1.988 . The gain value (D) is 468 , and the total square gain $\left(\mathrm{D}^{2}\right)$ classification, frequency, and percentage of students' scores in the pre-test and posttest are 10,192 .

\subsection{Pre-test}

A pre-test was given before students undergo treatment. It aimed to determine the reading ability of the students. The order of the tests is based on the purpose of reading ability. In this test, researchers took the test sequence using multiple choice.

After this, the students answered the questions given by the researcher. Before they worked on the questions given, the researchers explained clearly how to answer the question. In the test, the researchers found that some students and difficulty working on the questions given. Automatically, that student's pre-test scores are still low. For more details, the description will be explained as follows:

The illustrated below show that the highest score on their pre-test result was 84 consisting of one student and the lowest score was 48 , consisting of 2 students. 
Table 1. The Classification, Frequency, and Rate Frequency of the Students Score in Pre-test

\begin{tabular}{ccccc}
\hline \multirow{2}{*}{ No. } & \multirow{2}{*}{ Classification } & Score & Frequency & Pre-test \\
\cline { 3 - 5 } & & $93-100$ & 0 & $0 \%$ \\
\hline 1. & Very Good & $81-92$ & 1 & $4 \%$ \\
2. & Good & $73-80$ & 0 & $0 \%$ \\
3. & Fairly Good & $65-72$ & 3 & $12 \%$ \\
4. & Fair & $53-64$ & 18 & $72 \%$ \\
5. & Poor & $0-52$ & 3 & $12 \%$ \\
6. & Very Poor & & 25 & $100 \%$ \\
\hline
\end{tabular}

One student gets a score of 84 , which is classified as good. Two students get a score of 72 , which is classified as fair. Five students get a score of 64 who classified as poor out of 25 students. Six students get a score of 56, which is classified as an inferior category. Seven students get a score of 60 classified as poor, out of 25 students. One student gets a score of 52, classified as very poor. 2 students get a score of 48 , which is classified as very poor. One student gets 68 scores, which is classified as fair out of 25 students.

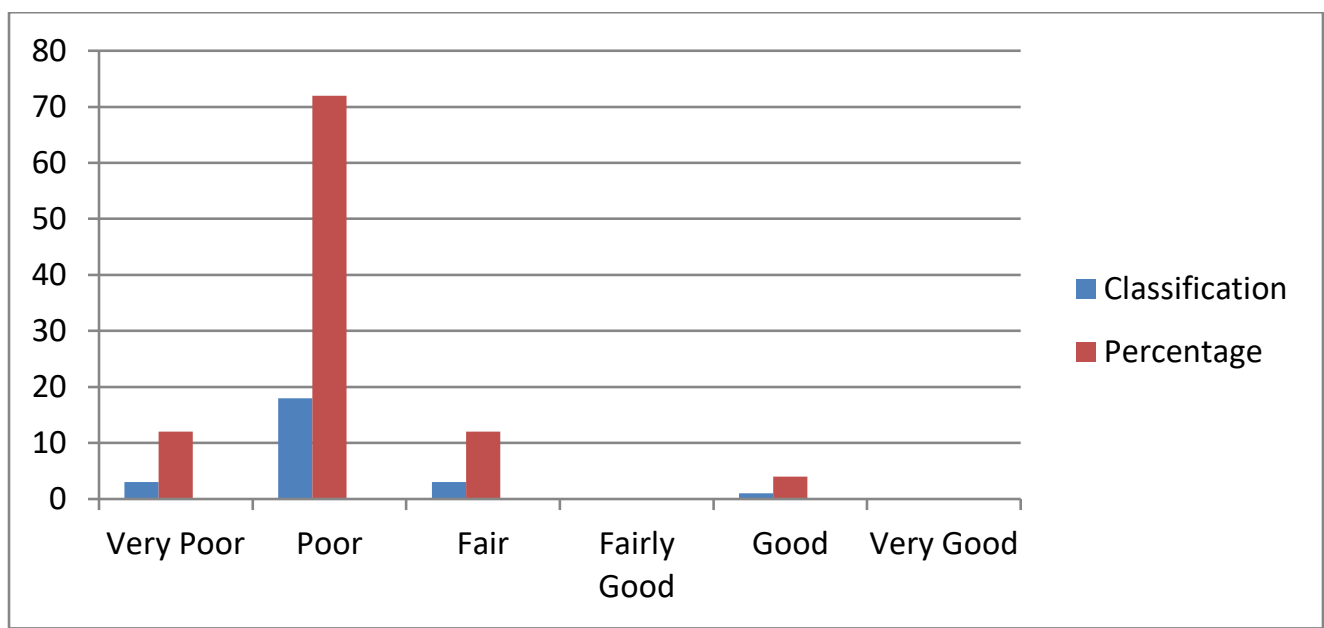

Figure 1. The graphic of the Pre-test

The figure above shows that there was category poor was higher before, through Phonics Reading. It can be concluded that students' reading ability at the second-grade students was still law category.

\subsubsection{Treatment}

After giving the pre-test, the researchers gave the students treatment to improve their reading ability using Phonic Reading. in treatment, the researchers explains the narrative text's material, namely parts of the narrative text. They especially understood the main ideas of the narrative text. The procedure for treatment from one today four is similar. In this treatment, students carry out learning activities that motivate them to learn and try challenging things, significantly improving their reading ability.

\subsubsection{Post-test}

To determine the students' understanding and the effectiveness of this strategy, the researchers prepared a second test. The researchers gave a post-test after the researchers gave treatment. This aims to determine the improvement of students reading ability after students have studied the narrative text and parts of narrative text. In this test, researchers tend to know the value of the result after treatment. It is expected that the student's post-test result score will be higher. Then the pre-test because the researchers has provided the material. In this test, the researchers found that the students looked easy in answering the question given. The facial expressions know it of the students, and they look relaxed and happy to finish the test. They did the post-test fast, and they had collected their answers before the time ran out. Of course, the student's posttest results improved. These findings are classified as follow:

According to the post-test result from the secondgrade students of SMP Negeri 2 Sumarorong, the table shows that the lowest score of the post-test was 64 and the highest was 100 from the total number of students was 25. From the score above, the researchers concluded that the reading ability of the students has improved. It means that the students were considered different after treatment. 
Table 2. The classification, frequency, and rate percentage of the students score in post-test

\begin{tabular}{lcccc}
\hline No. & Classification & Score & \multicolumn{2}{c}{ Post-test } \\
\cline { 3 - 4 } & & Frequency & Percentage \\
\hline 1. & Very Good & $93-100$ & 1 & $4 \%$ \\
2. & Good & $81-92$ & 8 & $32 \%$ \\
3. & Fairly Good & $73-80$ & 10 & $40 \%$ \\
4. & Fair & $65-72$ & 4 & $16 \%$ \\
5. & $53-64$ & 2 & $8 \%$ \\
6. & Poor & $0-52$ & 0 & $0 \%$ \\
\hline
\end{tabular}

The table above shows the percentage and frequency of students' post-test in learning Phonic Reading. From the table above where one student (4\%) who classified as very good, four students (16\%) are classified as good, five students $(20 \%)$ are classified as quite good, five students $(20 \%)$ classified is good enough. Moreover, one student $(4 \%)$ is classified as sufficient, where three students $(12 \%)$ are classified as fair, and two students (8\%) are classified as poor. It can be said that the percentage rate on the post-test is greater than on the pre-test.

The post-test results have shown that some of the second-grade students of SMP Negeri 2 Sumarorong got good grades. The researchers found that one student gets a score of 100, and 4 students got 92 out of 25 students. Students' scores on the post-test were better than students' scores on the pre-test.

The post-test results show that some of the secondgrade students of SMP Negeri 2 Sumarorong get good grades. The researchers found four students who got a score of 84 out of 25 students, the student's scores on the post-test were better than the students' scores on the pre-test. The post-test results show that some of the second-grade students of SMP Negeri 2 Sumarorong get good enough.

The description of the data above shows that in the post-test results, the student is dominant where one student got a score 100. The highest score for their post-test result was 92 consisting of four students, and the lowest score was 64 consisting of 2 students. Students get the highest score here to show that they can understand and know about letters' sounds.

The data clearly show that students' reading ability on the post-test is high. It is a significant difference before and after teaching reading through phonic reading.

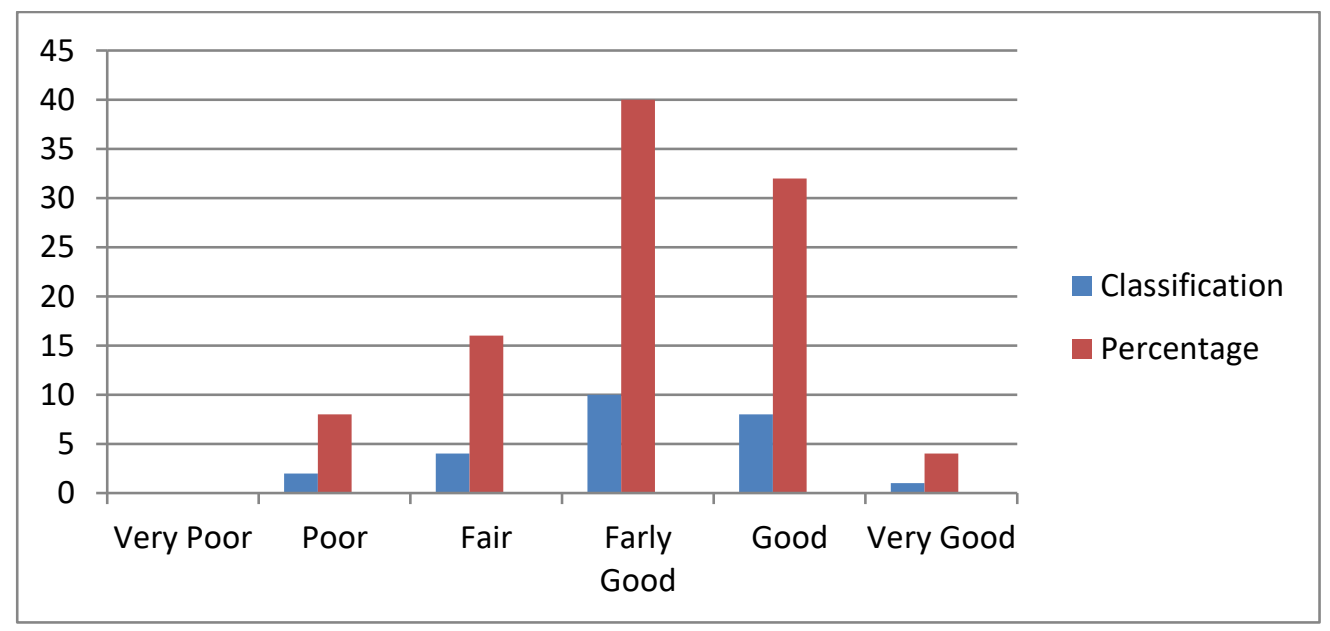

Figure 2. The graphic of the Post-test 
Figure 2 above shows that there was category fairly good was higher after the treatment through Phonics Reading. It can be concluded that students reading ability had been increasing after getting the treatment phonics reading. After doing the treatment through Phonics Reading, the researchers was conducting the post-test of the students. Moreover, the researchers found that the students' reading ability was significantly different between before and after the researchers did the treatment. From the graphic above data, it can be seen that there was category excellent, good, reasonably good, fair and poor after doing the treatment through phonics reading strategy in teaching reading ability.

\subsubsection{Analysis data using the formula:}

1) Mean Score of the students' Pre-test Where:

$$
\begin{gathered}
x 1=\frac{\sum x}{N} \\
x 1=\frac{1520}{25} \\
x 1=60,800
\end{gathered}
$$

The mean score of students' pre-test was 60,800

2) Mean score of the students' post-test.

Where:

$$
\begin{array}{r}
x 2=\frac{\sum x}{N} \\
x 2=\frac{1988}{25} \\
x 2=79,52
\end{array}
$$

The mean score of students' post-test was 79,52

3) The mean Score of Gain

Where:

$$
\begin{gathered}
D=\frac{\sum D}{N} \\
D=\frac{468}{25} \\
D=18,72
\end{gathered}
$$

The mean score of the gain (D) was 18.72

Table 3. The mean Score of Pre-Test and Post-Test

\begin{tabular}{cc}
\hline Mean Score of the Pre-test & Mean Score of the Post-test \\
\hline 60.800 & 79.52 \\
\hline
\end{tabular}

As we can see in the table above, the students' pretest score was 60.800 that can be classified into fairly good score classification, while the mean score of the students' post-test is 79.52 that classified as an outstanding score classification. So the researchers concluded that the mean score of the post-test was higher than the pre-test score. Through Phonics Reading Strategy, it could improve the reading ability of second-grade students of SMP Negeri 2 Sumarorong. Based on the data above would be applied in the figure below:

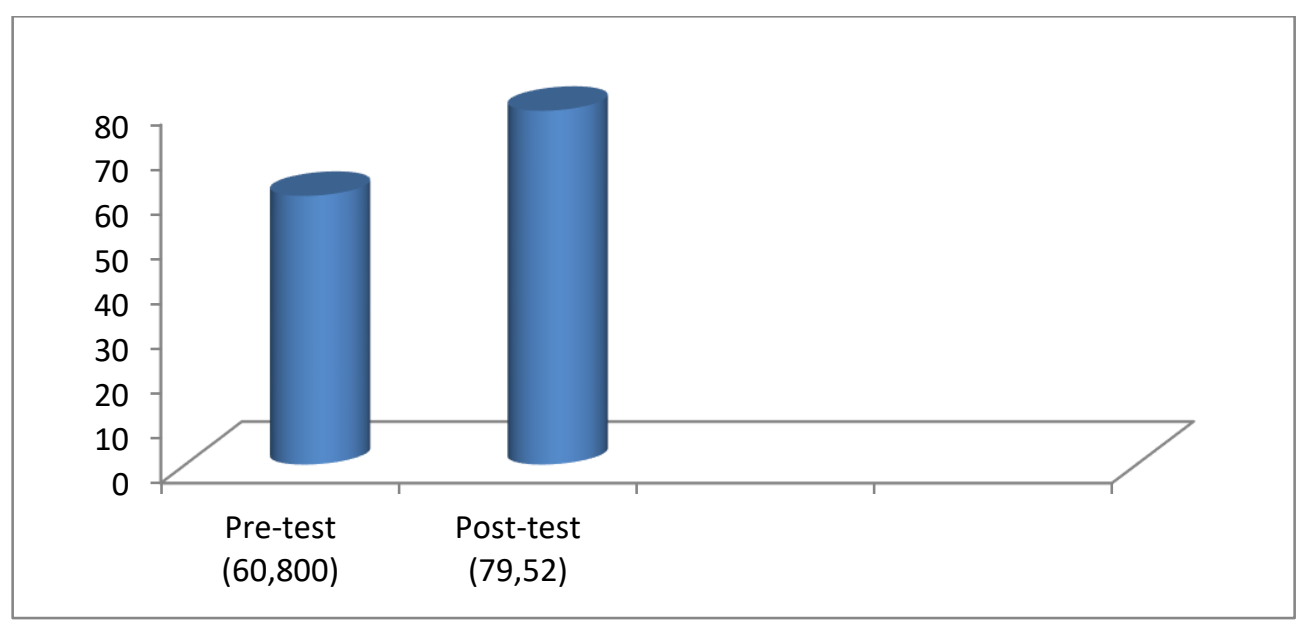

Figure 3. The graphic of Percentage of Frequency in the Pre-test and Post-test 
The figure above showed that the result of students' mean score in the post-test was higher than the result of students' mean score in the pre-test. There was a significant difference between before and after giving the treatment through phonics reading strategy.

4) T-Test Value

$$
t=\frac{\bar{D}}{\sqrt{\frac{\sum D^{2}-\frac{\left(\sum D^{2}\right)}{N}}{N(N-1)}}}
$$$$
t=\frac{18,72}{\sqrt{\frac{10192-\frac{468^{2}}{25}}{25(25-1)}}}
$$$$
t=\frac{18,72}{\sqrt{\frac{10192-\frac{219,024}{25}}{25(24)}}}
$$$$
t=\frac{18,72}{\sqrt{\frac{10192-8760}{600}}}
$$$$
t=\frac{18,72}{\sqrt{\frac{1432}{600}}}
$$

$$
\begin{gathered}
t=\frac{18,72}{\sqrt{2,38666666667}} \\
t=\frac{18,72}{1,54488403017} \\
t=12,04633204
\end{gathered}
$$

After the calculation, the t-test value $=12.04$ with the assumption of a significant level $(p)=0.05$, the degree of habit $(\mathrm{df})=\mathrm{N}-1=25-1=24$, and $\mathrm{T}$-table value $=2.046$. The table's data showed that the t-test is higher than the t-table value $(12.04>2.046)$. It can be concluded that there is a significant difference between the students' pre-test and post-test results after using the Phonics Reading method in reading learning. This means that the hypothesis (H0) of this study is rejected. The alternative hypothesis (H1) is accepted because there is a significant difference between the pre-test and post-test results after giving the treatment phonics reading. The t-test in this study also answers the hypothesis in this study that (H0) is rejected. There is no significant difference in students' reading skills before and after using the phonics reading method, and (H1) there is a significant difference in students' reading skills before and after using the phonics reading method. The results of the t-test can be seen in the following table:

Table 4. The Value of T-test and T-table

\begin{tabular}{lll}
\hline Variable & T-test Value & T-Table Value \\
\hline Pretest-Posttest & 12.046 & 2.046 \\
\hline
\end{tabular}

The table above showed that the t-table was smaller than the t-test value of the students' reading ability, where the value of the t-test was 12.046 while the value of the t-table was 2.046 . It can be inferred that there were significant differences between the result of the students' pre-test and post-test.

\section{5) Hypothesis Testing}

To find out the degree of freedom (Df), the formula was used in the following:

$$
\begin{aligned}
\text { Df } & =\mathrm{N}-1 \\
& =25-1 \\
& =24
\end{aligned}
$$

For a significant level $(\mathrm{P})=0.05$ and degrees of freedom $(\mathrm{df})=2.046$. Compared with the test value, it can be concluded that the t-test value (12.04) is higher than the t-table (2.046). On the other hand, the researchers said that $12.04>2,046$. This means that the hypothesis (H0) of this study is rejected, and the alternative hypothesis (H1) is accepted because there is a significant difference between the pre-test and posttest results using phonics reading to improve students' reading skills.

From the above analysis, the researchers conclude that there is a significant difference between the pretest and post-test results of students' scores after using the phonics reading method in reading learning for second-grade students of SMP Negeri 2 Sumororong. 
Table 5. Table of Significance

\begin{tabular}{cccc}
\hline Df & Level of Significance & T-test Value & T-table Value \\
\hline 24 & 0.05 & 12.046 & 2.046 \\
\hline
\end{tabular}

The table above shows that the t-table higher than the t-test 12.046 while the t-table 2.046. that is, there is a significant difference between the students' pre-test and post-test results.

\section{Discussion}

Based on the data above, it is clear that students' reading skills improve after received the treatment through phonics reading strategy In this study, the researchers gave a pre-test to students which aimed to improve their previous reading skills, there was only one student who got fair grades, and there were 18 students who failed the pre-test because of difficulties in reading sentences in English.

After giving the pre-test, students were taught to use the phonics reading method in four meetings, then the researchers gave a post-test to the students. There was one student who could pass the test and got excellent grades. There were eight students who got good grades as well after being given treatment since the students were able to pronounce the sentence correctly. Ten students got good enough grades, and four students got adequate grades, and two students got bad grades because some of them have difficulty pronouncing the English sentences.

This research aims to determine whether there is a significant difference between the pre-test and post-test results. After obtaining pre-test and post-test data, the researchers compared the students' pre-test and posttest results. In other words, the post-test result higher than the pre-test. Moreover, here are the details of the discussion and research findings to determine students' phonics reading strategy in learning English.

The discussion discusses the interpretation of findings obtained from data analysis. A description of the data collected through the reading test described in the previous section shows that the students' reading achievement section has improved. It is supported by the frequency percentage results and the percentage of students 'pre-test and post-test results. After presenting the material through the phonics reading strategy in the teaching and learning process of reading, the student's scores were better than before the treatment was given to them.

The following is a detailed discussion of student learning outcomes in the pre-test and post-test. It can be noticed that the total pre-test and the total post-test score is the selection between the matched pairs and the squared gain. It can be concluded that the total score of the post-test is higher than the total score of the students' pre-test after they used the phonics reading method. In the pre-test, the students' reading test percentage and frequency through phonics reading were classified as good or very good. Only one student was classified as good, 18 students were classified as bad, and three were classified as very bad.

Based on the pre-test, it can be seen that students find it challenging to analyze the reading text. Generally, their tongues are not trained in speaking English. According to (Hismanoglu, 2016), wrong pronunciation of words may not allow ideas or thoughts to be conveyed. Besides that, the inadequate ability in pronunciation often becomes an obstacle that causes students to be reluctant to use the foreign language being studied.

In this connection, reading plays a vital role in language acquisition because reading skills help students master all language skills: speaking, writing, listening, and reading. Reading is a fundamental skill in learning and a pivotal channel in dealing with outside world (Saeidmanesh, Hajavi and Moradi, 2018). Lucker (2018) states reading decoding requires looking at a written text and deciding what words are formed by sounding words. Students should have a good idea of developing reading skills to increase their interest in learning the language.

In the post-test results, the percentage level and frequency of texts about reading through phonics reading, there was one student classified as very good, eight students classified as good, ten students classified as good enough, four students classified as sufficient, and two students classified as bad. So it can be concluded that most of the students 'reading skills began to increase into a suitable category, namely as many as eight students, and it can be concluded that the level of achievement of students' post-test results has increased. It is connect with Wade-Woolley and Heggie (2016) idea that the texts they read become more and more like the dynamic of language they hear spoken around them, with its shades of meaning and connections to knowledge not specifically mentioned.

The result of this research is in line with several previous studies. Firstly, Cavalli et al. (2017), in their research entitled "Phonemic-Morphemic dissociation in dyslexia students and reading compensation index?" Expressing phonological deficit is the leading cause of phonological dyslexia measured in 20 dyslexic students and 20 non-dyslexic students. The results support the claim that students with dyslexia can compensate for phonological weakness by describing morphological knowledge in reading.

Mingazova, Subich, Al-foadi and Zakirov (2018), in their research entitled "Cognitive basis of phonogrammar in Russian and arabic" Reveals the direct relationship of the quantitative sound change from the consonant position to the process. Thought in which 
the human brain recognizes the language of categorization, identifies phonemic retrieval mechanisms, which are morphologically and syntactically modified. Moreover, Menin-sicard and Sicard (2107), in their research entitled "PhonoArticulatory Disorder and Intelligence: The Role Of Lingual and Palatal Reading." Demonstrating the relationship between disability and methodical and specific articulation disorders can improve speech intelligibility and phonological awareness, which is necessary for reading access.

De Freitas, da Mota and Deacon (2018), in their research entitled "Morphological Awareness, word reading, and reading comprehension in Portuguese." Investigates the unique effects of phonological awareness on several aspects of reading. The results showed that morphological awareness was a significant predictor of word reading accuracy. Morphological awareness also explains the unique differences in the understanding of the reading words as a control. Further, It did not take long for students to complete the reading test. In this case, the researcher succeeded in applying personal reading skills through phonics reading, looking at the data displayed, reading phonics in reading learning for students, especially the second grade of SMP Negeri 2 Sumarorong. Another particular case also shows the increase in students 'ability to improve their reading skills, as evidenced by the t-test. The t-test of this study is, and the t-table means that the t-test value is higher than the t-table value. So it was concluded that there was a significance between the students' pre-test and post-test results.

Students' mean score in the pre-test and post-test plays an essential role in determining a technique used in teaching and learning reading skills. Logically, if the average student score on the pre-test is higher than the average post-test score, it can be concluded that the technique used does not have a significant effect on the development of students' reading skills. Automatically the technique cannot be used to improve achievement. Their reading skills, on the other hand, if the average score of students on the pre-test is lower than the average post-test score of students, it can be concluded that the technique used has a significant effect on improving student reading achievement.

During treatment, researchers identified several problems that students experienced first; there was no interest in learning English. However, using suitable methods and learning techniques was enough to increase students' interest in learning English. First, students were noisy because they learned to read in the way of phonics reading. Second, they could not understand what the researchers explained in English. Therefore, researchers combine English and Indonesian to understand their explanations because reading makes them happy quickly. Then the researchers asked the students to stay focused and sit in their respective groups, then each group will listen to the audio, and each group will have a turn to read the narrative text from the audio that has been heard. After that, the researchers will reread the narrative text and ask students to follow. The researchers recorded the students' voices and played them back to each group. After that, the researchers explained the rules and procedures clearly to students. However, the students participate actively and enjoy the teaching and learning process. They show enthusiasm and interest in learning to read with phonics reading.

From the above statement, the researchers concluded that in learning English related to the reading process, the teacher needed to prepare ways to support students' learning, particularly in reading. Through Phono Reading as a way that aims to improve students' reading skills.

\section{Conclusion}

After researching improving students' reading ability through phonics reading in second-grade students of SMP Negeri 2 Sumarorong, the researchers concluded as follows: phonics reading is a way to improve the reading ability of second-grade students of SMP Negeri 2 Sumarorong in the 2020/2021 school year. There is a significant difference in student scores, and it can be seen from the results of the students' initial tests. Researchers have shown that the way phonics reading improves students' reading ability. It is evidenced by the pre-test and post-test results. The researchers found an increase in reading ability after being treated by reading phonics. The pre-test mean scores were 60,800 , and the post-test was 79.52. This means that the average post-test score of students is higher than the pre-test score. The development of students' reading ability in English was also evidenced by the t-test value, which was higher than the t-table value of 12.04> 2.046 at degrees of freedom (df) 25-1 $=24$ at the significant level $(\mathrm{p})=(0.05)$ that is, there is a significant difference in students' reading ability before and after being taught through phonics reading.

\section{References}

Amadi, E. A., \& Offorma, G. C. (2019). Original Paper Effects of Two Phonics Instructional Modes on English as Second Language Learners' Achievement in Reading.

Cavalli, E., Duncan, L. G., Elbro, C., El Ahmadi, A., \& Colé, P. (2017). Phonemic-Morphemic dissociation in university students with dyslexia: An index of reading compensation?. Annals of dyslexia, 67(1), 6384.

De Freitas Jr, P. V., da Mota, M. M. P. E., \& Deacon, S. H. (2018). Morphological awareness, word reading, and reading comprehension in Portuguese. Applied Psycholinguistics, 39(3), 507-525. 
Gray, C., \& Climie, E. A. (2016). Children with attention deficit/hyperactivity disorder and reading disability: A review of the efficacy of medication treatments. Frontiers in psychology, 7,988.

Hismanoglu, M. (2016). A study on English preparatory program EFL learners' beliefs about language learning in relation to gender, second foreign language knowledge and foreign country experience. International Journal of Applied Linguistics and English Literature, 5(5), 109-118

Lucker, J. R. (2018). Phonemic Awareness, Reading Abilities, and Auditory Processing Disorders. Auditory Processing Disorders: Assessment, Management, and Treatment, 391.

Menin-Sicard, A., \& Sicard, E. (2017). Phonoarticulatory disorders and intelligibility: role of lingual and palatal reading. Rééducation orthophonique. 231, 203-226

Mingazova, N. G., Subich, V. G., Al-foadi, R. A., \& Zakirov, R. R. (2018). Cognitive bases of phono-grammar in russian and arabic. Amazonia Investiga, 7(13), 162-167.

Paris, A. S. (2019). Phonics Approach in Teaching Reading. International Journal of Multicultural and Multireligious Understanding, 6(3), 204-210.

Retnomurti, A. B., Hendrawaty, N., \& Nurhayati, N. (2019). Strategi Pengenalan Membaca Phonics Method dalam Pengabdian kepada Masyarakat di Jakarta Selatan. JPP IPTEK (Jurnal Pengabdian dan Penerapan IPTEK), 3(1), 15-24.

Robertson, E. K., \& Deacon, S. H. (2019). Morphological awareness and word-level reading in early and middle elementary school years. Applied Psycholinguistics, 40(4), 1051-1071.

Saeidmanesh, M., Hajavi, H., \& Moradi, V. (2018). Evaluation of phonological awareness training on reading improvement and skills. Auditory and Vestibular Research, 27(4), 208-214.

Suganda, L. A. (2015). Teaching reading for young learners in EFL context. Journal of English Literacy Education, 2(2), 116-125.

Wade-Woolley, L., \& Heggie, L. (2016). The contributions of prosodic and phonological awareness to reading. Reading and Writing, 29, $1-12$.
Zein, S. (2017). The pedagogy of teaching English to young learners: Implications for teacher education. Indonesian JELT: Indonesian Journal of English Language Teaching, 12(1), 61-77. 